How to cite this article:

Sadekin, M. N., Alam, M. M., Al Abbasi, A. A., \& Saha, S. (2020). Analysis of trend and sources of government budget deficit financing in Bangladesh, 16, 129-144. https://doi.org/ $10.32890 /$ jis 2020.16 .8

\title{
Analysis of Trend and Sources of Government Budget Deficit Financing in Bangladesh
}

\author{
${ }^{1}$ Md Nazmus Sadekin, Md Mahbub Alam, Al Amin Al Abbasi \& Subrata Saha \\ Department of Economics, \\ Mawlana Bhashani Science and Technology University Santosh, \\ Tangail-1902, Bangladesh
}

'Corresponding author: sadekin08@gmail.com

\begin{abstract}
Budget deficit is one of the most significant macroeconomic issues which have been debated both in the academic and political arena since 1970s. This study aims to explore the current position of government budget deficit, its trends, and sources of budget deficit financing in Bangladesh, covering the duration between 1980 to 2018. Secondary data has been used which was collected from the Bangladesh Economic Review and the World Bank. Data has been analyzed through descriptive methods. The Government financing budget deficit from two sources like domestic and foreign sources. The study finds that Government finances most of its budget deficit from the domestic sources than foreign sources especially from non-banks sources due to the increase in the net sale of national savings certificates while borrowing from bank sources is on the decline. Along with the effective measures of generating more internal resources, the government should also focus on other areas to reduce the budget deficit. The government should be taking the approapriate steps to make progressively investable resources and generate a fund for financing the non-development spending in reducing the reliance on debt that can guarantee more distribution on the development sector.
\end{abstract}

Keywords: Budget deficit, deficit finance, domestic and foreign sources, non-bank sources, non-development expenditure.

\section{Introduction}

Budget deficit is one of the most important macroeconomic issues that have been debated since 1970 s in both academic and political arenas. Due to the structural problems, there were 
severe problems encountered in developing countries than in developed ones (Barisik \& Baris, 2017). Moreover, developed countries do not automatically suffer from the negative impact of budget deficits on macroeconomic balances as opposed to developing countries due to a relatively healthy foreign trade balance, reasonably large foreign exchange reserves, strong capital stocks, and low inflation levels (Samirkas, 2014). A comprehension of financing the budget deficit is additionally significant on the grounds that there are various ramifications of the strategy for loan financing within the economy. In general, deficit financing is met by borrowing from other sectors of the economy or international financial market, government borrowing from domestic sources, and, it also can be done by issuing government securities (Lwanga \& Mawejje, 2014).

Over the years, Bangladesh has experienced continuous budget deficits and rising debt levels accompanied by a fall in revenue sources. Even though the economy is growing, there is a slow-down within the growth because of increasing government expenditure relative to the revenue. Therefore, the financing of budget deficit requires more borrowing and external credits, because the collection of revenue is slower as opposed to total expenditure. There are various causes of budget deficits. The foremost being when the actual revenues collected fall short of the projected amount. This may be attributed to low economic performance affecting the power of the government to gather enough. The other causes may be due to the alters in weather outlook that suppresses the productivity of an economy, the uncertainty that dampens the travel industry, outer elements like the worldwide emergency that reduces the private and public speculations, catastrophic events like dry spells, floods, and tropical storms that demolish resources and hamper economic functions.

According to the Bangladesh Economic Review (2018), the total budget deficit (excluding grants) for FY 2017-18 was projected at BDT 1.120.41 billion, which is around five percent of GDP. In funding the deficit, the Government depends on both domestic and international sources. Domestic sources are growing steadily financing this deficit. In recent times the collection of funds from the selling of NSCs by the government has been increasing rapidly. Whereas in recent times borrowing money from the banking system has been in a downward trend. The NSD share as a percentage of GDP (2.1 percent of GDP) actually exceeded bank borrowing $(0.9 \%$ of GDP) in FY18. It can be argued that a decrease in borrowing from the banking system will stimulate investment by the private sector that reduces the crowdingout effect resulting from government borrowing from banking industries.

On the other hand, the fund raising from selling NSCs will induce savers by delivering positive real returns as well as ensuring the net marginal families' social safety. Although it has higher cost implications for the Government, it is true that for the economic development of our country deficit budget is important, but there remains a question of how far the maintenance of the amount of 5 percent of GDP, which is equivalent to almost 30 percent of the total budget, is reasonable. It is important to bear in mind that budget deficit increases the national debt, which will lead to more national debts requiring to pay higher interest and the greater interest cost plays a positive role to extend the budget deficit (Hossain, 2014). 
The pathway of deficit budgeting states that the fiscal responsibility act deficits should not exceed 3 percent of GDP (World Bank, 2010). According to Kwanashie (2013), these conditions are gained if the size of the total budget deficit is around 3 percent of GDP.

Bangladesh's macroeconomic stability relies heavily on government budget strategies. But reducing budget deficits is a dynamic mechanism that relies on a wide range of economic activities including external factors. Various studies (Abdullah, Azad, \& Siddiqua, 2018; Ahmad, 2018; Biplob, 2019; Hussain \& Haque, 2017; Rana \& Wahid, 2016) have been conducted on-budget deficit in Bangladesh. These studies were done with the budget deficit and economic growth in Bangladesh. Notably, none of these studies have focused on the sources of financing budget deficit in Bangladesh. There remains a huge gap in knowledge in these studies that this research seeks to accomplish. Therefore, this study, seeks to explore the current position of government budget deficit, its trends, and sources of budget deficit financing in Bangladesh during the periods between 1980 to 2018.

The remaining sections of this study are arranged as follows. Section 2 and 3 describes the objectives and methodology of the study respectively. In section 4 the results and discussion of this study are explained and section 5 describes the conclusion and policy implication of the results of this study.

\section{Objectives of the Study}

The main aim of this study is to examine the sources of budget deficit financing in the Bangladesh economy for the period between 1980-2018. The choice of this period is based on the availability of data. The particular objectives are as follows:

i. To analyse the present scenario of the budget deficit in Bangladesh.

ii. To investigate the various methods used by the Government of Bangladesh to finance the budget deficit.

\section{Literature Review}

Ahmed (2019) analysed the causes and cures of the budget deficit in Bangladesh established that the implementation of the budget generally relied upon the proper mobilization of domestic resources such as the tax revenue collection both from the sources of direct, and indirect taxes. But the tax revenue collection had not reached the expected level in Bangladesh. To decrease the budget deficit, the government should take efficient and appropriate measures of creating more domestic resources. Simultaneously to escape the shortage of the budget, the legislature should undertake steps to diminish public spending.

Lamichhane (2018) examined the source of budget deficit financing in Finland. This study demonstrated that in financing the government budget deficit, the contribution of 
economic growth was significant. Raising employment, increasing investment and exports, expenditure on education, empowering, and making development indicates a positive driver in restoring economic growth. Moreover, the aggregated obligation will leave an enduring blemish on the economy as it occured in the Finnish economy. Therefore, the study asserted that economic growth is simply the best financing solution to the 'manageability hole'. Impacts of budget shortfall was found from the contextual analysis which were abundant, an ascent in joblessness, decline in standard of living, increment in charge, increment in private sparing, a decline in public sparing, increment of owing debtors, and an increase in the financing cost.

Tung (2018) researched the impact of fiscal deficit on economic growth in Vietnam, by utilizing the Error Correction model. The experimental outcomes resulted in the cointegration nexus between fiscal deficit and economic growth in Vietnam. The study highlighted that fiscal deficit has a negative impact on economic growth both in the short and long-term.

Sutihar (2014) investigated the pattern and sources of financing the budget deficit in Nepal. Shortfall financing was developed as a significant apparatus of financing government spending. Three exist three fons of deficit financing like an external loan, local borrowing, and money balance. The examination finds that the portion of financial deficiency/GDP proportion is varied from 2.9 percent to 5.5 percent between 2000/01 to 2010/11. The local borrowing to budget deficit is very large. The portion of the fiscal deficit to expenditure ratio changed from 15.9 percent to 30.3 percent in a similar period. The yearly declining pattern of financial shortage to use proportion showed that the Govt. of Nepal will have the option to plan and report the reasonable spending plan in the distant future.

Kosimbei (2009) examined the macroeconomic performance and budget deficits in Kenya: an experimental investigation. There existed two reasons for the budget deficit in Kenya, for example, structural factors and expanding government spending. The examination was to explore the techniques for financing budget deficits. The results of the investigation indicate that the government was not borrowing significantly from foreign sources. The government pursued resources from the local economy as of 1981 to 1992 by vending depository bills and bonds, encouraged by the presence of a genuine and exclusively created budgetary intermediation framework. In any case, there was a striking improvement in the charge income after 2003, prompted a decrease in momentary getting and presentation of long haul obtaining instruments. Residential acquiring prompts them to exit the private ventures. Likewise, the sources of spending shortages include the following: level of the monetary turn of events, development of incomes, insecurity of government incomes, government power over consumptions, and the degree of government cooperation in the economy.

Haq (2001) examined the causes and effects of budget deficit financing in Pakistan set up that the extent of the deficit financing for improving economic growth in the reverse economy is exceptionally brilliant as they are trapped in an endless loop of underdevelopment. He noticed that such nations had used assets for speculation when the assets of the nation were not satisfactory to start the cycles of take-off, thus resulting in the requirement for deficient financing. 
Adesuyi and Falowo (2013) characterized deficiency financing as the net increment in the measure of cash available for use where such an expansion resulted from a cognizant governmental policy intended to empower monetary exercises which should not have occurred. Viably utilized, shortage financing could be an extremely amazing asset of capital arrangement to most creating nations. Jhingan (2002) likewise characterized deficiency financing along comparative lines; deficit financing alludes to the financing of the intentionally made hole between public income and spending, the technique for financing that outcomes in the net expansion to public cost or total spending. Generally the government funds its deficiencies in three primary manners, which are indicated by Emmanuel (2013) by incorporating printing of cash, financing debt, and drawing from the reserves of foreign exchange that was collected throughout the long term.

Chhibber and Wijnbergen (1998) contended in their with the Turkish data that an enormous budget deficit was financed by obtaining domestically hindered private investment making to raise the real interest rate. Majumder (2007) led an examination to look at the crowdingout impact in Bangladesh. Yet, he found that Bangladesh encountered crowding in instead of crowding out due to the overabundance of liquidity regulating the banking system.

There are questionable thoughts on the connection between economic growth and budget deficit: the Keynesian analysts contended that there existed a positive connection between the two arrangements, the neo-classical analysts contend the inverse, while, the Ricardian identicalness speculation asserts that there was unbiased nexus between budget deficit and economic growth in a nation. A review of previous investigations found that budget deficits have an inverse effect on economic growth (Adeoye, 2006; Akinmulegun, 2014; Awe \& Funlayo, 2014; Haider, Shaon, \& Kabir, 2016; Keho, 2010; Oladipo \& Akinbobola, 2011; Muzib, Liton, Sadekin, \& Mahmud, 2014) while other studies showed that the financing of the deficit had the positive effect of economic growth (Adesuyi \& Falowo, 2014; Antwi et al., 2013; Emmanuel, 2013; Hassan \& Akter, 2014; Rana \& Wahid, 2017; Mushtaq \& Zaman, 2013; Tung, 2018). In this manner, although various studies have been conducted on-budget deficit in Bangladesh, however none of these studies have focused on the sources of budget deficit financing in Bangladesh. Therefore, the current study is very significant.

\section{Research Methodology}

This study is adopted as a descriptive method for science. The descriptive research style, according to Bryman (2003), is a scientific method involving observing and explaining a subject's behaviour, without influencing it in any way. Its purpose is to give a picture of a situation as it happens naturally (Burns \& Grove, 2007). The descriptive analysis aids the study to take into account the important aspects of the phenomenon and gives clear information on every concerned variable. This analysis used data from the annual time series spanning the period from 1980 to 2018. The research is based on the secondary data from the Bangladesh Economic Review released by the Ministry of Finance and Benson and Clay (2002) expressed by the World Bank. The data is analyzed using descriptive methods. Graphical research is conducted with the data obtained to achieve the study's objectives. 


\section{Findings and Discussion}

The size and the composition of public expenditure is an important factor as it affects the existence of budget deficit. Using the fiscal instrument of taxation, expenditure, and borrowing governments mobilize resources to the arrangement of publicly provided goods and services with a higher objective of attaining better economic growth, manipulate the economy, and the public expenditure is becoming a growing concern in almost all developing countries (Mulugeta, 2018). In this section, the study shows the trend of government revenue and expenditure and focuses on the structure and trend of a budget deficit. It also describes methods of financing budget deficits in Bangladesh.

\section{Trend in Government Revenue in Bangladesh}

Tax revenue is the principal source of government revenue. Public revenue essentially comprises of direct and indirect taxes and they represent in excess of 80 percent of the total government revenue. The remainder of the revenue income originates from various non-tax sources, for example, expenses, charges, tolls, and other relevant streams. The amount of revenue is one of the recognized criteria for judging the phase of the economic development of a nation.

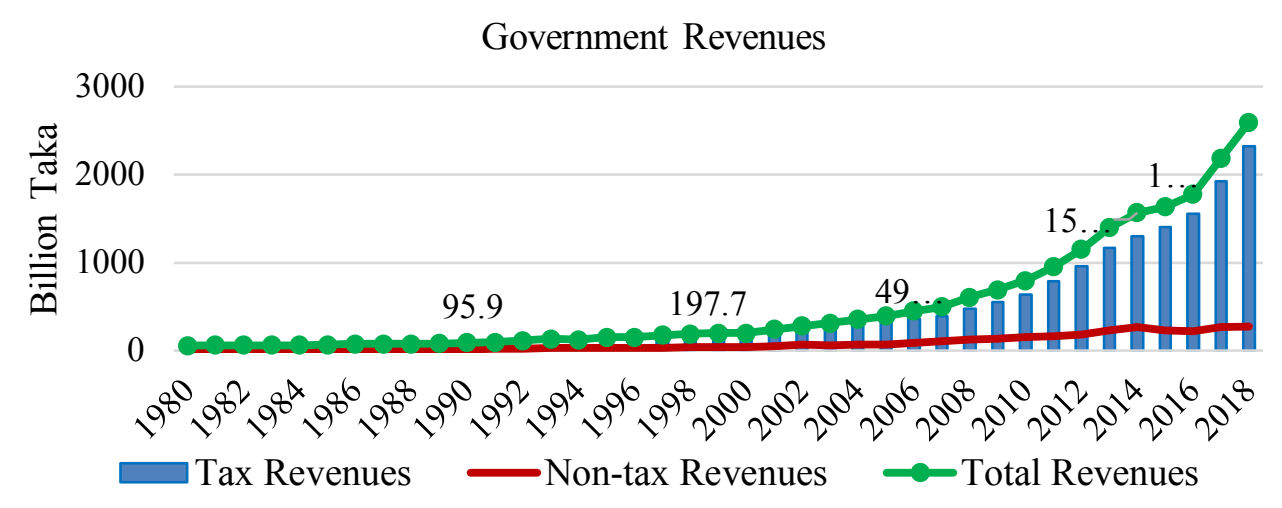

Source: Bangladesh Economic Review (2005, 2018).

Figure 1. Trend of Government Revenue from 1980 to 2018 in Bangladesh.

Figure 1 shows the total revenue (tax and non-tax revenue) during the period from 1980 to 2018. Initially since 1980, the government revenue was increasing at a slow pace until 1991. Then the trend of government revenue increased sharply at a higher pace up from the beginning of 2000 to 2018. Debilitation in the effort to mobilize domestic resources is the great structural suppress confronting the Bangladesh economy during the 1980s. The total 
government revenues was BDT 67.46 billion. The portion of revenue (both taxes and nontaxes revenue) raised from BDT 95.9 billion in 1991 to BDT 354 billion in 2004. Following the early 1990s performance in income earnings, the income mobilization process began to demonstrate indications of weariness. The introduction of VAT significantly influenced the rise in the early 1990s. VAT offered a greater source of income comparaed to the taxes it supplanted, especially with regard to the local creation tax collection. The plunge in the mid1990s is predicated largely by the demolishing floods of 1998. Most recovery was executed in 2001, where BDT was reported at 243.4 billion for the collection of total income, which is 9.6 percent of GDP and raised to 10.87 percent in 2004. Such an accomplishment is conceivable gratitude to awesome achievement in meeting the NBR 's goal for revenue collection.

The average increasing rate of revenue between the years 2011 and 2016 is BDT 1197.37 billion as against that of BDT 458.1 billion for the years between 2005 and 2010. Total revenue receipts increased by 11.5 percent and stand at Tk. 2,594.54 billion in 2018 compared to Tk. 2,185 billion in 2017. It is pertinent to say that the vital reason behind such an increase of revenue is the result in the increase of tax income which is the major revenue for the state, financing public spending and different expenses, substantially communicating the basic endeavors of the community. The subsequent endeavors to widen the tax base and fortify assessment organization through computerization, charge instruction, and implementation estimates drove the expansion in incomes on benefits and VAT. However, in one area where the performance of the country has been disappointing is the revenue mobilization. Revenue effort (i.e. Revenue to GDP ratio; less than $12 \%$ in 2018) has been one of the lowest in the World. This, though, is not a recent phenomenon. Historically, revenue mobilization has been poor in Bangladesh. Meanwhile, given the fast-expanding tax bases (especially the domestic tax bases for income tax and VAT due to sustained $13 \%$ nominal GDP growth) as well as the revenue efforts of countries with comparable per capita income, setting a target of around 12 to 13 percent appears to be on the lower side. Bangladesh should have set revenue targets of a minimum of 15 to 17 percent of GDP.

\section{Trend in Government Expenditure in Bangladesh}

Government spending typically represents public expenditure on goods and services and is a significant feature of GDP. Government expenditure is applied to the current expenditure and investment by the central authority of a country to satisfy the different social and political needs. Government expenditure in modern government finance is regarded as a means of securing social ends rather than just being mere finance mechanisms, government expenditure is significant in a modern economy because it produces money directly and indirectly to socio-economic effect (Mankiw, 2000). Government spending in Bangladesh has been tending to rise from its start. The increase in government spending is far greater than the national income.

Figure 2 shows starting from 1980 government expenditure was increasing at a slower pace until 1998 and it also increases from 1999 to 2006. Then the share of government 
expenditure sharply increases at a higher pace up from the beginning of 2007 to 2018 . In the 1980s, average government expenditures are BDT 135.63 billion. Throughout the 1990s, government expenditures have raised. But in the first half of the 1990s, the average share of government spending is lower compared to the second half. For example, the government spending on average, is BDT 189.9 billion during the 1991-1995 period, while the equivalent amount for the subsequent period 1996-2000 is BDT 274.68 billion. After those decades in the 2000 s, expenditures are increased stridently further.

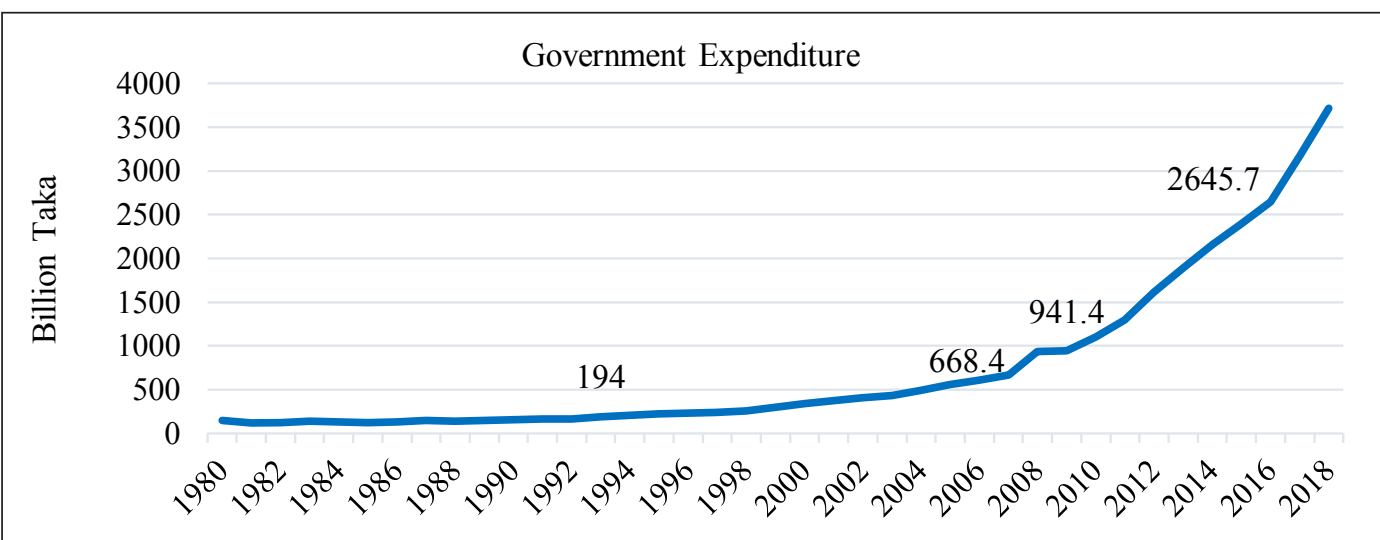

Source: Bangladesh Economic Review (2005, 2018).

Figure 2. Trend of Government Expenditure in Bangladesh from 1980 to 2018

The average government expenditures in the first half of the 2000s are BDT 453.72 billion and again start to increase BDT 852.34 billion in the latter half of that period, recording at its top in 2010 (13.9\%). Moreover, government spending kept rising because of exercises by the administration to battle neediness and build up a productive domain through the improvement in the nature of instruction, upgraded proficiency in the open help, access to medicinal services, and backing for poor individuals through social awards. The share of average government expenditures increases from BDT 1300.1 billion in 2011 to BDT 2396.7 billion in 2016. In the last three years (2016-2018), the average government expenditures are BDT 3177.46 billion. Total expenditure is increased by 17.13 percent to BDT 3714.95 billion in 2018 from BDT 3171.74 billion in 2017.

\section{Present Scenario of Budget Deficit in Bangladesh}

The government of Bangladesh has been experiencing a consistent and increasing budget deficit but the question of whether it contributes to good or poor economic performance is what the study intends to investigate. To decrease the deficit, the government needs to extend its efforts in mobilizing income whereas keeping up it's spending beneath watch at the same time (Muriithi \& Moyi, 2003). This is on the grounds that development in 
government spending raises the budget deficit if income is not developing at a similar proportion and it is declined if the expansion in income is depleted in poor and inefficient social projects. In Bangladesh, the trends of the budget deficit between the period 1980 and 2018 are highlighted in Figure 3.

Since independence, Bangladesh has been experiencing a consistent and increasing budget deficit. During the 1980s, Bangladesh has confronted an intense emergency of uneven characters asset. In a nascent economy, there are enormous weights on public spending comparative with the inconsequential income base, which causes inappropriate budget deficit. The enormous number of misfortune-making state ventures within the generally nationalized economy contributed to the asset trouble, and the nation's improvement spending is massively complete through benefactor assets. Monetization of government shortages and unfriendly developments as far as the exchange, particularly in the consequence of the subsequent oil-value stun, added to a sharp decay in lopsided macroeconomic characteristics. These prompted an important budget deficit to remain at BDT 65.2 billion (11.7\% of GDP) during the 1980s.

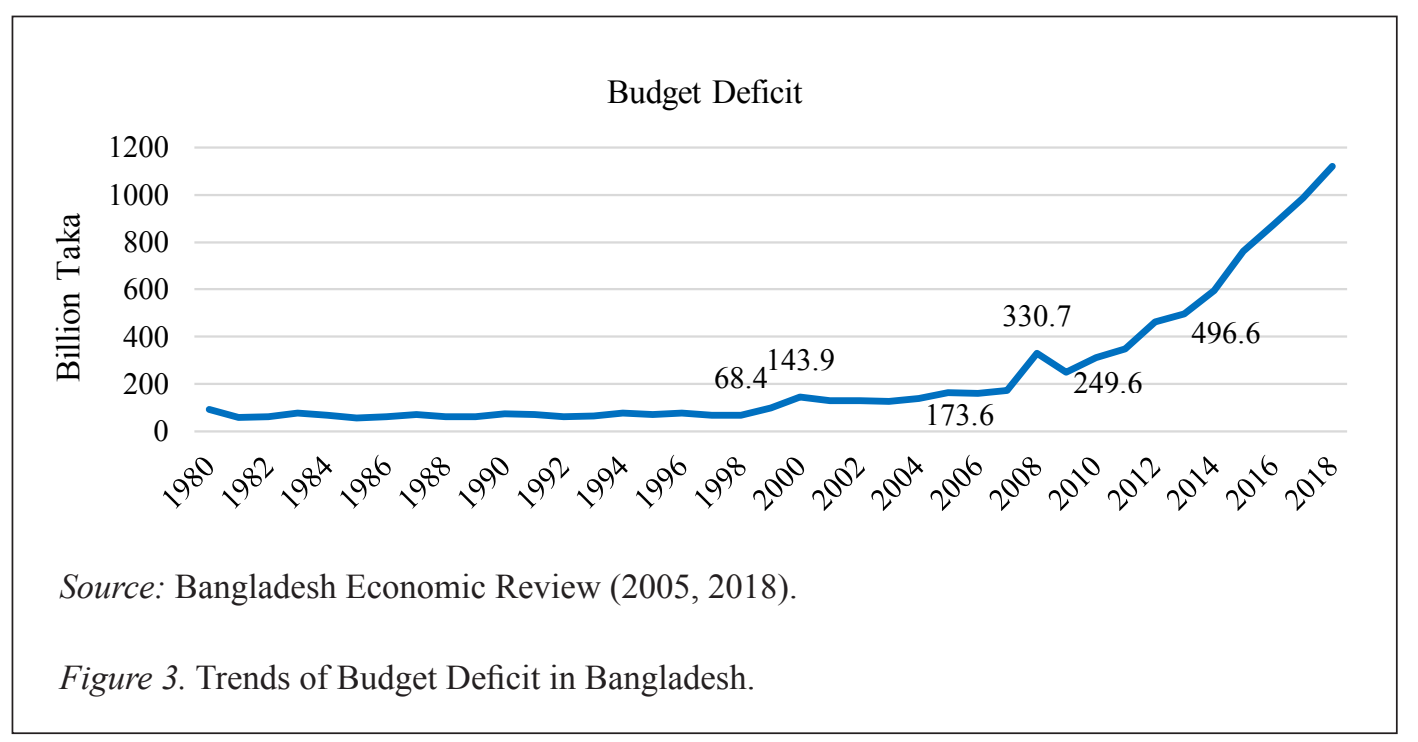

In early period of $1990 \mathrm{~s}$, a higher level of the budget deficit is performed but the portion has diminished toward the end of the period from 6.5 percent in 1991 to 4.6 percent in 1995 . In the first half of the 1990s, the average budget deficit is BDT 69.52 billion (5.5\% of GDP) but after that, it accelerated to BDT 91.54 billion (4.5\% of GDP) in the second half of the decade. The budget deficit suddenly expanded in 1999 followed by a staggering flood in 1998. However, in the presence of the increasing demand for expenditures and lower than forecast revenue collection, was largely due to the flood-related expenditures. The overall budget stands at BDT 80.53 billion at the end of the 1990s. However, within the sight of expanding demand for spending and lower than gauge income assortment, generally on the 
account of flood-related consumptions, the total budget stands at BDT 80.53 billion towards the end of the 1990s.

The average budget deficits in the first half of the 2000s are BDT 137.8 billion and again starts to increase to BDT 245.24 billion in the second half of that period. Between the years 2011 and 2015, the average government budget deficits are BDT 116.72 billion. In recent periods the budget deficit has expanded at a faster rate. Over the most recent three years (2016-2018), the average government budget deficits are BDT 992.92 billion. The total budget deficit is increased by 13.55 percent to BDT 1120.41 billion in 2018 from BDT 986.74 billion in 2017. However, the government utilizes this money directly or indirectly for the welfare of the public and for the improvement of the economy. Therefore, Bangladesh has adopted an expansionary economic policy as it directs ample capital to suitable directions that lead to poverty and sustain economic growth in the nation.

\section{Methods of Financing of Budget Deficits in Bangladesh}

The financing of the budget deficit is essential for a country's fiscal and monetary authorities, as it is very effective in allocating resources between the private and public sectors. A lack of a suitable funding mix for deficits may also distort an economy's monetary transmission process Besides, high government debt accumulated from a high budget deficit will threaten debt sustainability and bring sluggish economic activity. With regard to deficit financing, the government in Bangladesh mainly accumulates loans from domestic and external sources. Over the past seven or eight years, Bangladesh has funded much of its fiscal deficit by borrowing domestically before the deficit financing depended heavily on foreign borrowings. Bangladesh banks, scheduled banks, and other non-bank financial organizations which are the principal sources of domestic borrowing. External funding sources are multilateral loaning foundations, for example, the IMF, World Bank, and the Asian Development Bank, other streams and various countries. The borrowings from the banking sector increasingly emerged because of the key source of deficit financing in Bangladesh. The following is an explanation of each of the methods of deficit financing.

\section{Domestic Financing}

Domestic resources are often regarded as the Goverment's primary source to finance deficits. The Government borrows from two domestic sources: the banking industry, and the non-banking market. In recent times, the Bangladesh government finances most of its budget deficit from the domestic sources, especially from the banks. However, the actual scenario is different as the government raises money from selling savings certificates above the budgeted figure, which ultimately reduces the burden for the government to borrow from banks. The Govt is domestically borrowing higher. The NSD certificates reflect sluggish demand for private sector investment funds. A large amount of bank borrowing by the government will deflect the income in the private segment, thus, allowing the government to obtain the reserves from different sources, such as infrastructure funds and bonds, and other money-related instruments. 


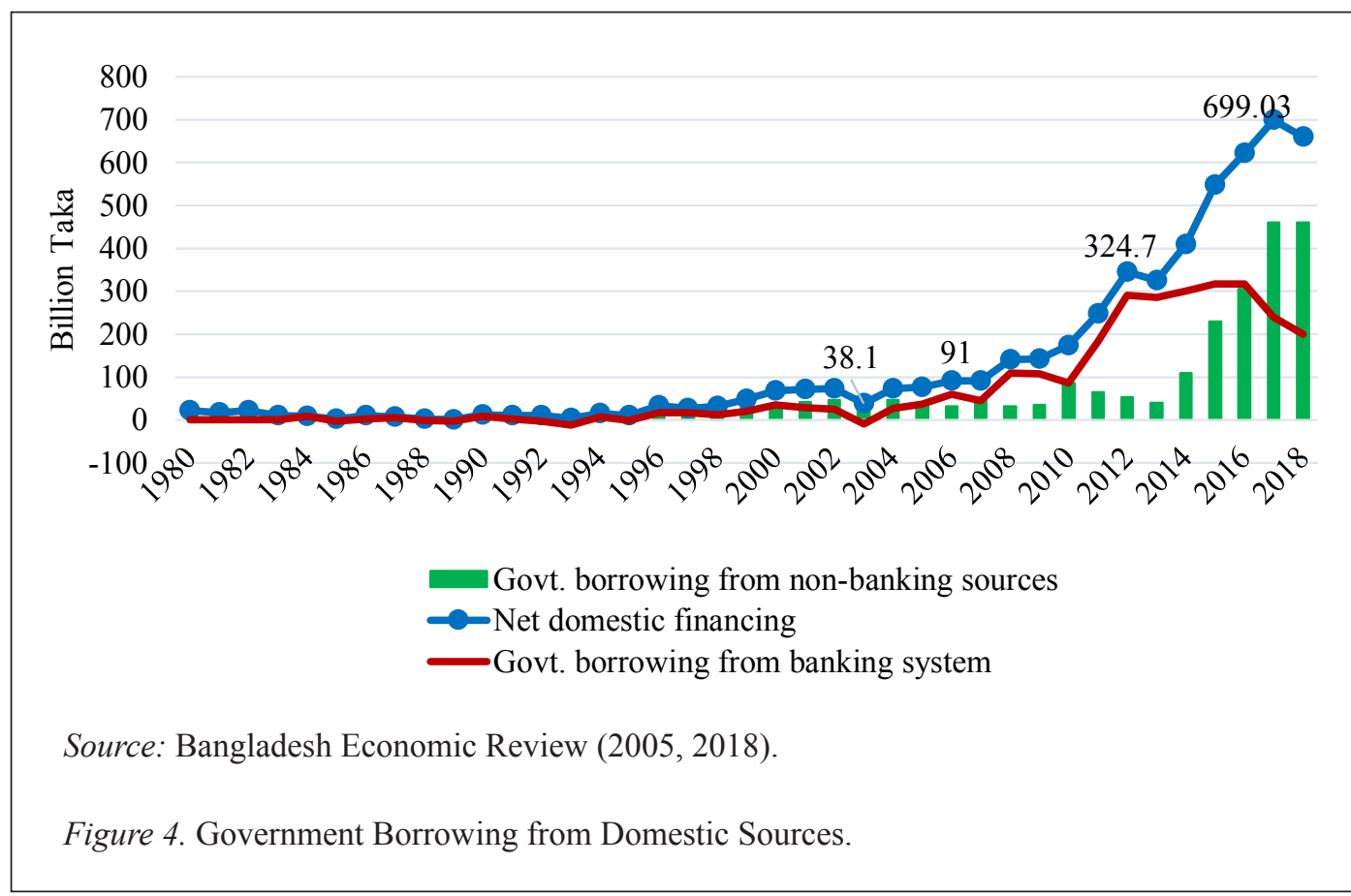

In Figure 4, the domestic borrowing, which stands at BDT 21.5 billion during 1980, rose to BDT 660.17 billion in 2018. Domestic financing shows a rising trend since 2010 due to the rise in the deficit. The domestic borrowing in 2010 is BDT 173.2 billion and become BDT 324.7 billion in 2013 and BDT 409.8 billion in 2014 and BDT 547.1 billion in 2015 and BDT 621.7 billion in 2016 and BDT 699.03 billion in 2017. However, net govt. domestic borrowing during 2018 is BDT 660.17 billion which is smaller than that of the past year. Among domestic sources, the amount of borrowing from bank sources is higher than that from the non-bank sources in 2008-2016. The borrowing from bank sources is BDT 109.6 billion in 2008 while it stands at BDT 31.4 billion from non-bank sources at that period. On the other hand, in 2016 borrowing from bank sources stand at BDT 316.7 billion while it stands at BDT 305 billion from non-bank sources. In recent times, borrowing from the banking sector is decreasing.

The structure of deficit financing in recent years has been characterized by low net admission from external funding sources as compared to substantial dependence on internal sources. Inside the domestic funding structure, excessively selling of high yielding NSD is again the major contributor in 2018. Since the selling of NSD certificates has already secured a large share of the funding, the need for bank borrowing may be very small. Government net borrowing from the banking system decreases BDT 239.03 billion in 2017 and BDT 199.17 billion during 2018 while net govt. borrowing from the non-banking sources (including Treasury Bills and Bonds and savings instruments) increased BDT 460 billion in 2017 and Tk. 461 billion in 2018. Among the domestic sources, borrowing from non-bank sources 
has been on the rise mainly due to the increase in a net sale of national savings certificates (NSD) while borrowing from bank sources is on the decline.

\section{Foreign Financing}

External support has played an important role within the economic improvement of Bangladesh helping in connecting the interior gap (savings-investment gap) and the external gap (export-import gap) (Sadekin, Muzib, \& Al Abbasi, 2015). In recent years, the trend of budget deficit shows a steady decline of dependence on external assistance. But the principal and interest repayment for received loans by Bangladesh is gradually increasing. As a result, the pace of increment of the net flow of external resources becomes slow, and sometimes this flow also reduces. There is an increase in the outflow of budgetary resources that lessens the net progression of foreign funding resources to Bangladesh. The budget deficits are heavily financed by external resources in the early 1980s and 1990s, in the form of Official Development Assistance ( ODA). Therefore, 86 percent of the ADP was funded by the ODA in 1991, and 4.81 percent of GDP is the net foreign financing of the budget deficit.

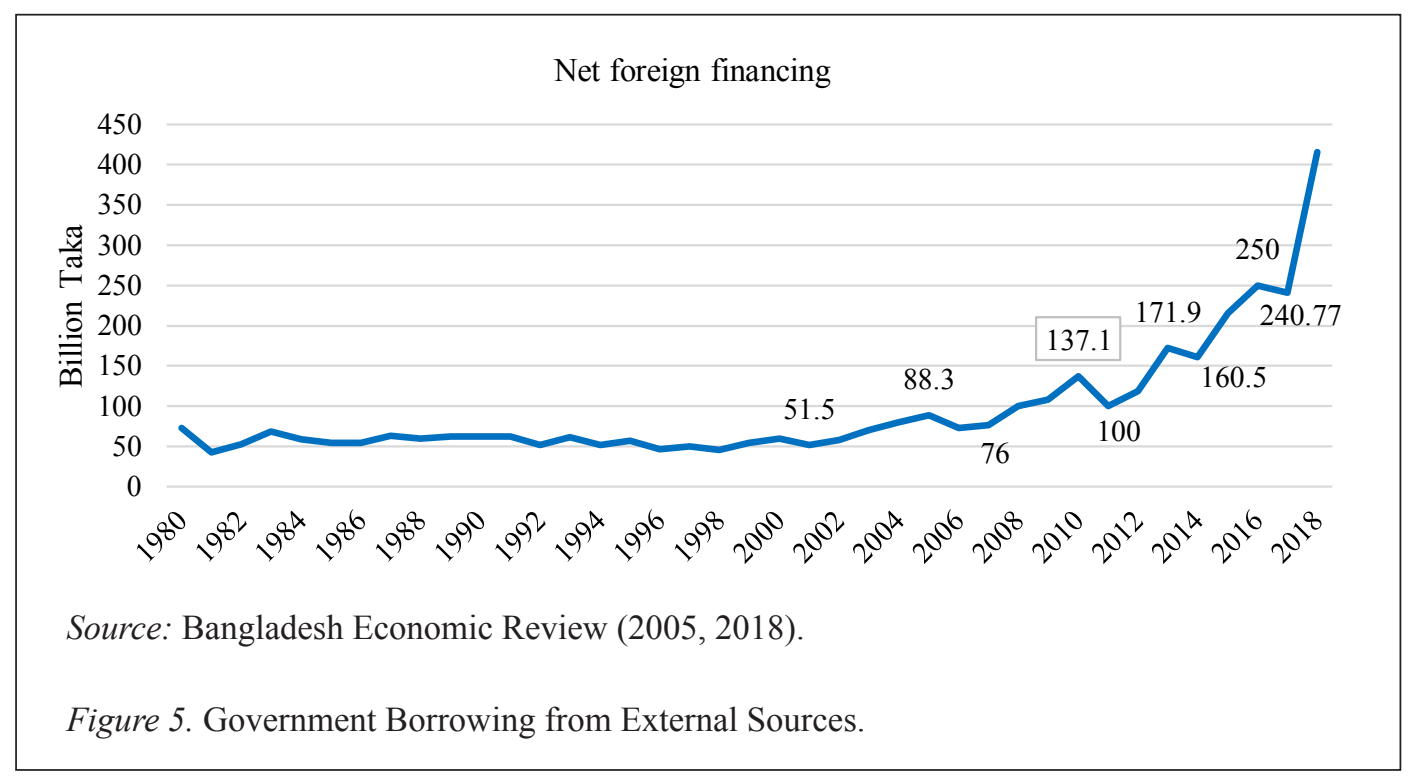

During the 1990s, the amount of external funding diminished to 3.21 percent at the end of the primary half. The cumulative share of the budget deficit is primarily funded from domestic sources, and net international funding dropped sequentially in the early 2000 s. The external resource has got a significant increasing trend between 2012 and 2018. Analyzing the data from outer sources indicates that in 2018, the number of foreign resources stands at BDT 415.67 billion which is 72.64 percent higher than the receipt BDT 240.77 billion of the 
previous year, 2017. This was because Bangladesh earned some commitment for prominent and nationally important projects such as Ruppur Nuclear Power Plant and Padma Railway Link projects. In the similar manner, the disbursement amount increased in FY2017-18 due to the Russian disbursement for Ruppur Nuclear Power Plant project which started that year.

\section{Conclusion}

The descriptive analysis has expressed that the general trend for government expenditure has been persistently increasing in Bangladesh throughout the study period due to the expansion of the public sector economy. In a similar pattern, the government revenue has also increased during duration of the research, but it fails to catch up with the growth of government expenditure that deficit starts since independence and has been growing ever seen. In turn, this has created a budget deficit as it is not followed by equally proportionate growth revenue. Since 1984, the large and rapid expansion of state activity within the economy has led to the growth of both government revenue and spending with the dominance of the latter. As a result, the budget deficit is growing over time. It has been argued that the causes of the rising budget deficit is mainly caused by the growth of expenditure over revenue. Apart from this, there are four reasons as to why the government may open to high budget deficit level, political reasons, that governments may deliberately favor high spending levels and low tax rates to make their government legitimate; structural reasons; which makes the economy inflexible within the short term; inflation, that reduces the real balance of tax revenue as a result of the existence of collection lags and finally theorizing development.

The descriptive analysis for financing the deficit shows that the way of finance is shifted from foreign sources to the domestic resources. In recent times, among the domestic sources, borrowing from non-bank sources has been on the rise mainly due to the increase in the net sale of national savings certificates (NSD) while borrowing from bank sources is on the decline. Budget implementation largely depends on the appropriate mobilization of internal resources i.e., collection of tax revenue from both direct and indirect tax sources. Collecting taxes is a mountainous job. While developed countries have been able to collect taxes to the required level in most of the cases, developing countries like Bangladesh struggle to collect the same. However, the tax GDP ratio is still low relative to other neighboring nations. The size of the budget is being increased every year and more money is to be invested into the exchequer through the collection of taxes. On the contrary, the collection of revenue has yet to reach the expected level. There are various multiple causes which are ranging from weak tax administration, corruption, narrow tax base, tax avoidance by MNCs, lack of tax culture, and a variety of others.

Under the circumstances, it is imperative that to increase tax revenue and reduces the budget deficit, the government should be made the fundamental reform of tax structures and the reform should focus on broadening the tax bases (as opposed to mounting high tax rates), minimize tax exemption and improve the tax administration system which affects the tax-collecting systems and reduce unnecessary and unrealistic public expenditure. The 
government should implement the appropriate steps to ensure more investment resources or to set up a fund to finance non-development expenditure to reduce debt dependency, ensuring more allocation to the development sector as to reduce debt dependency. Otherwise, the continuing budget deficit will reign the economy of Bangladesh for the future and put the economy at stake.

\section{Acknowledgement}

This research received no specific grant from any funding agency in the public, commercial, or not-for profit sectors.

\section{References}

Abdullah, S. M., Azad, A. K., \& Siddiqua, S. (2018). Budget deficit and growth: In search of ceiling for bangladesh. Business and Economic Horizons, 14(4), 743-765. https:// doi.org/10.15208/beh.2018.52

Adeoye, T. (2006). Fiscal policy and growth of the Nigerian economy. Nigerian Institute of Social and Economic Research Monograph Series, 3.

Adesuyi, O. O., \& Falowo, E. (2013). Impact of fiscal deficit financing on macroeconomic growth in Nigeria. International Journal of Research in Management, 3(5), 143-172.

Ahmad, F., \& Rahman, B. (2017). The relationship between budget deficit and economic growth : A study on Bangladesh. ASA University Review, 11(2), 1-13.

Ahmed, S. U. (2019). Budget deficit in Bangladesh : Causes and remedies. The Cost and Management, 47(03), 43-48.

Akinmulegun, S. O. (2014). Deficit financing and economic growth in Nigeria: A preliminary investigation. British Journal of Economics, Management \& Trade, 4(11), 1624-1643.

Antwi, S., Zhao, H., \& Mills, E.F.E.A. (2013). Consequential effects of budget deficit on economic growth: Empirical evidence from Ghana. International Journal of Economics and Finance, 5(3), 91-101.

Awe, A. A. \& Funlayo, A. K. (2014). The short and long-run implications of budget deficit on economic growth in Nigeria (1980-2011). Canadian Social Science, 10(5), 201205.

Barisik, S., \& Baris, A. (2017). Impact of governance on budget deficit in developing countries. Theoretical and Applied Economics, 24(2), 111-130.

Benson, C., \& Clay, E. (2002). Bangladesh: Disasters and public finance. Working Paper Series, 6, the World Bank, Washington, D.C. Retreived from https://www.odi.org/ sites/odi.org.uk/files/odiassets/publications-opinion-files/4794

Biplob, M. N. K. (2019). Does budget deficit impede economic growth? Evidence from Bangladesh. Journal of Management, Economics, and Industrial Organization, 3(2), 66-94. https://doi.org/10.31039/jomeino.2019.3.2.5

Bryman, A. (2003). Integrating quantitative and qualitative research: how is it done? Qualitative Research, 6(1), $97-113$. 
Burns, H., \& Grove, G. (2007). Understanding nursing research - Building an evidencebased practice (4th edition). Saunders Elsevier.

Chhibber, A., \& Wijnbergen, S. V. (1998). Public policy and private investment in Turkey. RePec: http://ideas.repec.org/p/wbk/wbrwps/120.html

Emmanuel, U. C. (2013). An analysis of the relationship between fiscal deficits and selected macroeconomic variables in Nigeria, 1970-2011. IOSR Journal of Business and Management (IOSR-JBM), 12(6), 19-27.

Haider, A. S., Shaon, S. F., \& Kabir, M. R. (2016). Impact of budget deficit on growth : An empirical case study on Bangladesh.

Haq, A. U. (2001). Causes and effect of deficit financing. Deficit Financing: http://www. easypublish.com

Hassan, M. H., \& Akhter, A. (2014). Budget deficit and economic growth of Bangladesh : A VAR-VECM Approach. Janata Bank Journal of Money, Finance and Development, $1(2), 98-110$.

Hossain, M. S. (2014). An analysis on macroeconomic performance of Bangladesh. The Institute of Chartered Accountants of Bangladesh, 1-30.

Hussain, M. E., \& Haque, M. (2017). Fiscal deficit and its impact on economic growth : Evidence from Bangladesh. Economies, 5(37), 2-19. https://doi.org/10.3390/ economies 5040037

Jhigan, M. L. (2002). Macroeconomic theory. Vrinda, Delhi.

Keho, Y. (2010). Budget deficits and economic growth: Causality evidence and policy implications for WAEMU countries. European Journal of Economics, Finance and Administrative Sciences, 99-104.

Kosimbei, G. K. (2009). Budget deficits and macroeconomic performance in Kenya: An Empirical Analysis (Vol. 2), (Unpublished doctoral dissertation), Kenyatta Unviersity, Nairobi, Kenya.

https://ir-library.ku.ac.ke/bitstream/handle/123456789/474/George\%20 Kipng\%E2\%80\%99etich\%20Kosimbei.pdf

Lamichhane, N. (2018). Financing government budget deficit: The case study of Finland (Unpublished master's thesis). Unviersity of Vaasa, School of Management.

Lwanga, M. M., \& Mawejje, J. (2014). Macroeconomic effects of budget deficits in Uganda: a VAR-VECM approach. Journal of Science and Technology, 4(6), 1-7.

Mankiw, N. G. (2010). Macroeconomics (Seven ed.). New York: Worth Publishers.

Majumder, A. M. (2007). Does public borrowing crowd-out private investment? The Bangladesh evidence. Working Paper Series: WP 0708, Policy Analysis Unit.

Mulugeta, A. (2018). The determinants of budget deficit in Ethiopia. Addis Ababa, Ethiopia.

Muriithi, M. K., \& Moyi, E. D. (2003). Tax reforms and revenue mobilization in Kenya. African Economic Research Consortium Research Paper 131.

Mushtaq, A., \& Zaman, K. (2013). Macroeconomic factors affecting budget deficit in Pakistan: A time series analysis. Oeconomics of Knowledge, 5(4), 17-33.

Muzib, M. M., Liton, M. R., Sadekin, M. N., \& Mahmud, M. A. (2014). The target and achievements of private sector credit in Bangladesh: A monetary policy analysis. Global Disclosure of Economics and Business, 3(3), 68-77. 
Oladipo, S. O., \& Akinbobola, T. O. (2011). Budget deficit and inflation in Nigeria: A causal relationship. Journal of Emerging Trends in Economics and Management Sciences, 2(1), 1-8.

Rana, E. A., \& Wahid, A. N. M. (2016). Fiscal deficit and economic growth in Bangladesh : A time-series analysis. The American Economist, 62(1), 1-12. https://doi. org/10.1177/0569434516672778

Sadekin, M., Muzib, M., \& Al Abbasi, A. A. (2015). Contemporary situation of FDI and its determinants: Bangladesh scenario. American Journal of Trade and Policy, 2(2), 121-124.

Samirkas, M. (2014). Effects of budget deficits on inflation, economic growth and interest rates: Applications of Turkey in 1980-2013 period. Journal of Economics and Development Studies, 2(4), 203-210. https://doi.org/10.15640/jeds.v2n4a14

Sutihar, D. N. (2014). An analysis of trend and sources of deficit financing in Nepal. Economic Literature, xii(8-16), 8-15.

Tung, L. T. (2018). The effect of fiscal deficit on economic growth in an emerging economy: Evidence from Vietnam. Journal Of International Studies, 11(3), 191-203. doi:10.14254/2071-8330.2018/11-3/16

World Development Indicators. (2018). https://datacatalog.worldbank.org/dataset/worlddevelopment-indicators. 